\title{
Retraction Note: An augmented Riesz decomposition method for sharp estimates of certain boundary value problem
}

Jiaofeng Wang ${ }^{1}$, Bin Huang ${ }^{2}$ and Nanjundan Yamini ${ }^{{ }^{*}}$

The original article can be found online at https://doi.org/10.1186/ s13661-016-0664-x

"Correspondence: nanjundan.yamini@gmail.com ${ }^{3}$ Department of Mathematics and NTIS, University of West Bohemia PIzen, Czech Republic Full list of author information is available at the end of the article

\section{Retraction note}

The Editors-in-Chief have retracted this article [1] because it shows evidence of peer review manipulation and authorship manipulation. In addition, the identity of the corresponding author could not be verified: the University of West Bohemia have confirmed that Nanjundan Yamini has not been affiliated with their institution. The authors have not responded to any correspondence regarding this retraction.

Author details

${ }^{1}$ Mathematical and Statistical Sciences, Vocational and Technical College, Quzhou, China. ${ }^{2}$ Mathematical and Statistical Sciences, Quzhou University, Quzhou, China. ${ }^{3}$ Department of Mathematics and NTIS, University of West Bohemia, Plzen, Czech Republic

\section{Publisher's Note}

Springer Nature remains neutral with regard to jurisdictional claims in published maps and institutional affiliations.

Published online: 24 February 2020

References

1. Wang, J., Huang, B., Yamini, N.: Bound. Value Probl. 2016, 156 (2016). https://doi.org/10.1186/s13661-016-0664-X

\section{Springer}

(c) The Author(s) 2020. This article is licensed under a Creative Commons Attribution 4.0 International License, which permits use, sharing, adaptation, distribution and reproduction in any medium or format, as long as you give appropriate credit to the original author(s) and the source, provide a link to the Creative Commons licence, and indicate if changes were made. The images or other third party material in this article are included in the article's Creative Commons licence, unless indicated otherwise in a credit line to the material. If material is not included in the article's Creative Commons licence and your intended use is not permitted by statutory regulation or exceeds the permitted use, you will need to obtain permission directly from the copyright holder. To view a copy of this licence, visit http://creativecommons.org/licenses/by/4.0/. 